\title{
LAND PAYMENT AS AN INSTRUMENT OF PUBLIC WELFARE FISCAL REGULATION
}

The article is dedicated to the disclosure of social aspects of land taxation in Ukraine. It is justified that in modern conditions the land tax has a significant potential as a regulator of public welfare, but this potential is not fully used. From the point of view of taxation technique, the land tax, more than other components of the property tax, complies with the principle of fairness, as the tax base is the value of land. But, in many communities regulatory and monetary land valuation is outdated and needs updating in modern conditions. However, the author designates that the elements of the tax that, in fact, offset the regulatory potential of land tax are its rates and the list of exemptions. The categorical approach to the providing of exemptions and unreasonably low tax rates make the land tax fiscally insignificant and practically imperceptible for individuals - landowners. Many landowners in Ukraine haven't got documents proving ownership of their land shares. They don't pay land tax, which violates the taxation fairness principle. It is found that local governments often set low land tax rates because they protect the interests of government officials and try to avoid public discontent. The contingent calculation of the level of tax liability for land tax using the most difficult circumstances of its application (which in practice do not occur) has proved that it is very low. This has led to the conclusion that land taxation norms in Ukraine protect the interests of landowners and do not contribute to the redistribution of wealth from rich to poor. It is proved that the lack of a free land market leads to a lack of income by landowners. Determining the value of land shares (units) for the calculation of rent is carried out by the using of the normative-monetary assessment, which is much lower than the actual value of land. As a result, the unearned income of landowners is, in terms of regions of the country, from a few percent to several times. Lack of associations that would protect their interests also leads to the loss of rental income by landowners. Because of this, in the market of privately owned land, the "buyer's market" is often formed, that causes a loss of income of landowners.

Key words: land payment, land tax, land rent, monetary valuation, land share, tax exemptions, public welfare.

DOI: https://doi.org/10.32838/2523-4803/70-3-44

УДК 336.027

Григоришин Н.O.

аспірант кафедри економіки та економічної безпеки, Львівський державний університет внутрішніх справ ORCID: https://orcid.org/0000-0002-2312-4968

Grygoryshyn Nazarii

Lviv State University of Internal Affair

\section{СУЧАСНІ ТЕНДЕНЦІЇ ТА ІНСТРУМЕНТИ МОНЕТАРНОЇ ПОЛІТИКИ В УКРАЇНІ}

\footnotetext{
У статті розглянуто та проаналізовано роль монетарного регулювання, значення та функиіі Національного банку України у стимулюванні економічного розвитку в умовах фінансової нестабільності. Автор дослідив основні засади монетарної політики НБУ у 2010-2020 рр., а також інструменти та монетарні індикатори розвитку грошово-кредитної сфери. Особливу увагу акцентовано на основних тенденціях монетарної політики НБУ упродовж 2014-2020 рр. На основі класифікаціі тендениій сучасної монетарної політики НБУ автор дійшов висновку, щчо більшість проблем, які перешкоджали реалізації ефективної грошово-кредитної політики та розвитку банківської системи, подолано: інфляиія перебуває в допустимих межах, банки мають досить капіталу та ліквідності, щзоб відновити кредитування економіки, щзо дасть змогу подолати сучасну кризу та відновити економічний розвитку України.

Ключові слова: Національний банк України, монетарна політика, глобальна фінансова криза, девальвація та інфляція, монетарні інструменти, функиії цчентрального банку.
}

Постановка проблеми. Сучасний стан розвитку світової фінансової системи характеризується зміною ролі та функцій центральних банків у монетарному регулюванні економіки, що зумовлено фінансовими проблемами та дисбалансом у структурі фінансового ринку та державних фінансах окремих країн. Загальною тенденцією монетарної політики стало посилення ролі центральних банків у врівноваженні фінансових ринків та фінансових систем, введенні макропруденційних норм, посиленні координації грошово-кредит- 
ної та фіскальної політики; адекватне реагування на девальвацію та інфляційні процеси; вжиття заходів щодо посилення фінансової стабільності банківських систем та захист їх від системних ризиків.

Аналіз останніх досліджень і публікацій. Дослідженню ролі монетарного регулювання та функцій центральних банків у стимулюванні економічного розвитку в умовах фінансової нестабільності присвячено чимало наукових праць відомих вітчизняних $\mathrm{i}$ зарубіжних учених. Зокрема, В.С. Стельмах висвітлив сучасні аспекти монетарної політики Національного банку України (НБУ) та його роль у забезпеченні стабільності національної грошової одиниці [1, с. 404], Ф.С. Мишкін - сучасні аспекти монетарного регулювання та управління інфляційними процесами [2, с. 963]. О.В. Дзюблюк у своїх працях обгрунтував актуальні проблеми монетарного регулювання та інфляційного таргетування [3, с. 7-19; 12, с. 7-18.]. В.В. Коваленко дослідив вплив грошово-кредитної політики на подолання структурних дисбалансів у економіці та питання забезпечення стабільності банківської системи [4, с. 445-449]. С.В. Міщенко особливу увагу приділив стійкості грошового обігу й циклічності грошово-кредитного регулювання [5, с. 399; 14, с. 230].

Постановка завдання. Роль центральних банків у фінансовій системі монетарного регулювання економіки значно розширилася та ускладнилася. Зросло їх значення в управлінні монетизацією та стимулюванні економічного зростання. Вони змушені поєднувати виконання функцій із реалізацією економічної політики, особливо у сфері валютного та антикризового управління, стримування інфляції та забезпечення фінансової стабільності. Такі зміни необхідні, щоб зосередити увагу на ролі та функціях центральних банків, розробленні та впровадженні нових підходів, методів та інструментів регулювання грошових та фінансових ринків на основі відповідної монетарної політики.
Виклад основного матеріалу дослідження. Відповідно до Конституції України, Національний банк як головний орган державного регулювання у межах своїх повноважень здійснює комплекс взаємопов'язаних заходів, спрямованих на досягнення цілей монетарної політики та стійкого економічного зростання за забезпечення стратегічних цілей економічної політики.

Основні засади грошово-кредитної політики Національний банк України почав офіційно оприлюднювати з 2002 року. Документ містить інформацію щодо політики, яку центральний банк має намір реалізовувати в поточному році, а також щодо застосовуваних інструментів та монетарних індикаторів розвитку грошовокредитної сфери [13, с. 37-44].

Динаміку основних монетарних показників України у 2010-2020 рр. наведено у таблиці 1, однак грунтовне дослідження тенденцій монетарної політики здійснимо за період 2014-2020 pp.

Упродовж 2014-2015 рр. «пріоритетною метою грошово-кредитної політики» НБУ було «досягнення та підтримка цінової стабільності в державі», що вимірювалася індексом споживчих цін у межах 3-5\% на рік [15; 16]. Інакше кажучи, економічні і політичні проблеми, з якими зіткнулася Україна у ці роки, зумовили реалізацію обмежувальної монетарної політики, спрямованої на швидке подолання ознак інфляції та забезпечення внутрішньої фінансової стабільності.

Головним інструментом рестрикційної монетарної політики в Україні у 2014-2015 рр. була визначена облікова ставка, яка доповнювалася постійно діючими кредитним та депозитним механізмами овернайт.

Фактично, аналізуючи результати монетарної політики 2015 р., доходимо висновків, що НБУ зумів забезпечити технічні передумови для переходу до режиму інфляційного таргетування, зокрема: було побудовано макроекономічні моделі, розроблено квартальний прогнозний цикл, створені інституційні передумови, у

Таблиця 1

Основні монетарні показники України у 2010-2020 рр. (на початок періоду)

\begin{tabular}{|c|c|c|c|c|c|c|c|c|}
\hline \multirow[b]{2}{*}{ Рік } & \multirow{2}{*}{$\begin{array}{l}\text { Кількість } \\
\text { банків, од. }\end{array}$} & \multirow{2}{*}{$\begin{array}{c}\text { Інфляція, } \\
\%\end{array}$} & \multirow{2}{*}{$\begin{array}{c}\text { Облікова } \\
\text { ставка } \\
\text { НБУ *, \% }\end{array}$} & \multirow{2}{*}{$\begin{array}{c}\text { Курс } \\
\text { валют, } \\
\text { грн за } \\
100 \text { дол. } \\
\text { США }\end{array}$} & \multirow{2}{*}{$\begin{array}{c}\text { Кредити, } \\
\text { надані банками } \\
\text { в економіку } \\
\text { України, млн грн. } \\
\text { (за рік) } \\
\end{array}$} & \multirow{2}{*}{$\begin{array}{c}\text { Приріст кредитів, } \\
\text { наданих банками в } \\
\text { економіку України } \\
\text { (до попереднього } \\
\text { року), \% } \\
\end{array}$} & \multicolumn{2}{|c|}{$\begin{array}{c}\text { Грошова маса, } \\
\text { млн. грн }\end{array}$} \\
\hline & & & & & & & M0 & M1 \\
\hline 2010 & 182 & 112,3 & 9,9 & 779,12 & 723295 & $-1,5$ & 157029,41 & 233748,44 \\
\hline 2011 & 176 & 109,1 & 7,75 & 793,56 & 732823 & 1,3 & 182989,9 & 289893,6 \\
\hline 2012 & 176 & 104,6 & 7,56 & 796,76 & 801809 & 9,4 & 192664,8 & 311046,6 \\
\hline 2013 & 176 & 99,8 & 7,25 & 779,1 & 815142 & 1,7 & 203245,0 & 323225,3 \\
\hline 2014 & 180 & 100,5 & 6,62 & 799,3 & 910782 & 11,7 & 237776,6 & 383820,7 \\
\hline 2015 & 163 & 124,9 & 28,04 & 1576,86 & 1020667 & 12,1 & 282947,1 & 435474,7 \\
\hline 2016 & 117 & 143,3 & 17,95 & 2400,07 & 981627 & $-3,8$ & 282672,8 & 472217,1 \\
\hline 2017 & 96 & 112,4 & 13,2 & 2719,09 & 998682 & 0,7 & 314392,1 & 529928,0 \\
\hline 2018 & 82 & 113,7 & 17,08 & 2806,72 & 1016657 & 1,9 & 332546,0 & 601631,3 \\
\hline 2019 & 77 & 109,8 & 17,16 & 2768,83 & 1073131 & 13,7 & 363628,8 & 671284,7 \\
\hline 2020 & 77 & 100,8 & 8,0 & 2693,78 & 971871 & $-9,4$ & 384366,2 & 770043,1 \\
\hline
\end{tabular}

** середньорічні облікова ставка

Джерело: розроблено автором на основі [Офіџійний сайт НБУ URL: https://bank.gov.ua/] (дата звернення: 20.04.2020) 
тому числі забезпечена незалежність Національного банку у використанні інструментів для досягнення своєї цілі, усунене фіскальне домінування, змінений процес прийняття рішень із монетарної політики.

На початку 2016 року Національний банк перейшов до застосування режиму інфляційного таргетування. Схвалення Радою Національного банку Основних засад монетарної політики на 2017 рік та середньострокову перспективу в грудні 2016 року юридично закріпило інфляційне таргетування як режим монетарної політики в Україні.

Саме застосування режиму інфляційного таргетування дало змогу скоротити індекс інфляції 2016 р. до $12,4 \%$ порівняно із 43,3\% 2015 р., або на 30,9 в.П., що стало значним досягненням монетарної політики та позитивно вплинуло на стабілізацію національної економіки - ВВП уперше продемонстрував приріст $+2,9 \%$ у доларовому еквіваленті (2015 p. - 31,3\% у доларовому еквіваленті).

У наступний період 2017-2019 рр. вектором монетарної політики також було визначено забезпечення цінової стабільності та утримання інфляції в межах запланованого показника: 2017 p. $-8 \% \pm 2 \%$; 2018 р. $-6 \% \pm 2 \% ; 2019$ і надалі $-5 \% \pm 1 \%$. Тобто пріоритетом діяльності Національного банку України стало зниження інфляції до однозначного показника та утримання його на такому рівні в середньостроковій перспективі.

У 2018 р. Рада Національного банку затвердила Стратегію монетарної політики, офіційно закріпивши незмінність цілей та принципів реалізації монетарної політики. Послідовність у проведенні монетарної політики на основі режиму інфляційного таргетування посприяла стабілізації інфляційних очікувань населення та бізнесу, заохотила довгострокові заощадження та інвестиції в економіку.

Основні засади грошово-кредитної (монетарної) політики НБУ на 2018 рік визначили, що «формування низькоінфляційних очікувань $є$ одним із ключових елементів поліпшення макроекономічного середовища та нарощення економічного потенціалу України. Середньострокова ціль щодо інфляції (приріст індексу споживчих цін у річному вимірі) установлена на рівні 5\% із допустимим діапазоном відхилень \pm 1 п.п. і досягатиметься протягом 2018-2020 років».

В «Основних засадах грошово-кредитної політики на 2019 рік та середньострокову перспективу» НБУ знову задекларував «використання монетарного режиму інфляційного таргетування, оскільки досягнення цінової стабільності найкраще корелює із забезпеченням стійких темпів приросту ВВП й усуває передумови непередбачуваних та суб'єктивно вмотивованих рішень щодо змін у монетарній політиці» [7]. Цей же документ визначив кількісну ціль щодо інфляції $5 \%$ у середньостроковій перспективі. Водночас у Законі України «Про Державний бюджет України на 2019 рік» прогноз темпу інфляції було закладено на рівні 7,4\% [8].
У 2020 р. основними пріоритетами монетарної політики також було визначено «досягнення та забезпечення цінової стабільності» через «використання монетарного режиму інфляційного таргетування, який водночас сприяє забезпеченню стійких темпів приросту ВВП».

Проте світова пандемія COVID-19 похитнула сформовану стабільність на грошовому ринку: через карантин і паніку серед населення наприкінці прослідковувався шок у вигляді ситуативного послаблення гривні та ажіотажного підвищення попиту на окремі товари упродовж перших тижнів карантину (березень-квітень 2020 р.). Однак завдяки очищенню банківської системи, фіскальній консолідації, плаваючому курсу та більш дієвій монетарній політиці така ситуація виявилася короткостроковою.

Рівень інфляції у перші місяці 2020 р. залишався нижчим, ніж прогнозувалося. Очікується, що в наступні місяці 2020 р. зростання цін помірно прискориться внаслідок березневого послаблення гривні. Однак надалі інфляція обмежуватиметься падінням споживчого попиту i збереженням низьких цін на енергоносії.

Водночас варто зазначити, що підвищений попит на товари першої необхідності та ажіотаж на валютному ринку, спричинений психологічними чинниками, досить швидко вичерпалися. Ці чинники не будуть надалі значно впливати на інфляційну динаміку, на відміну від ефекту згортання внутрішнього попиту та суттєвого зниження світових цін на енергоносії.

Прогноз щодо майбутньої динаміки інфляції передбачає, що, незважаючи на помірне прискорення в наступних місяцях, інфляція залишиться в цільовому діапазоні $5 \%$ +/-1 в.п. і на кінець 2020 р. становитиме $6 \%$. Але слабший споживчий попит, ніж передбачено прогнозом, може зумовити повільніше повернення інфляції до цільового діапазону.

Водночас економіка потребує рішучого реагування та підтримки з боку НБУ. Наприкінці квітня 2020 р. Правлінням Національного банку України було встановлено облікову ставку на рівні 8,0\% річних [11].

Підводячи підсумки провадження монетарної політики НБУ, можна систематизувати основні напрями монетарної політики України упродовж 2010-2020 pp. [9].

1. Упродовж досліджуваного періоду 2010-2020 pp. НБУ здебільшого реалізовував жорстку рестрикційну політику «дорогих грошей» із незначними пом'якшеннями наприкінці 2018-2019 рр., про що свідчить рівень облікової ставки НБУ та обсяг кредитів, наданих банками в економіку держави.

2. Беззаперечним пріоритетом монетарної політики було досягнення та підтримання цінової стабільності порівняно з іншими цілями та завданнями у грошово-кредитній сфері, що постійно відображалося в Основних засадах грошово-кредитної політики на поточний рік. Національний банк не використовував жодних інструментів монетарної політики для досяг- 
нення будь-яких цілей, які б загрожували досягненню цінової стабільності.

3. Основним інструментом монетарної політики впродовж останніх років залишалася облікова ставка, яка оперативно змінювалася залежно від ситуації у фінансовій сфері. Найбільший вплив зміна облікової ставки справляла на рівень інфляції, оскільки давала змогу скоротити обсяг грошової маси в обігу. Водночас зростання облікової ставки негативно впливало на розвиток та зростання національної економіки та гальмувало ії вихід із кризового стану.

4. Рішення щодо параметрів монетарної політики грунтувалися на комплексному макроекономічному аналізі та прогнозі. Усі рішення мали перспективний характер.

5. Було впроваджено режим плаваючого обмінного курсу, який визначається ринковими умовами без попереднього встановлення бажаного або прогнозного значення.

6. Відбулося посилення прозорості діяльності НБУ, що відобразилося в оприлюдненні інформації на офіційному сайті у Річному звіті НБУ, Інфляційному звіті
Національного банку України, Звіті НБУ про фінансову стабільність, постійних прес-релізах щодо базових рішень регулятора у сфері грошово-кредитної політики, проведення наукових семінарів, конференцій.

Основні тенденції монетарної політики НБУ упродовж 2014-2020 pр. зображено на рис. 1.

Таким чином, дослідивши монетарну політику НБУ у ретроспективі 2014-2020 pp., іiї інструменти та результати, можемо дійти певних висновків щодо ролі монетарної політики у розвитку національної економіки, іiї позитивних та негативних аспектів впливу на фінансово-економічну систему держави.

Враховуючи вище означені тенденції, варто зазначити, що більшість проблем, які перешкоджали реалізації ефективної грошово-кредитної політики та банківської системи, подолано, інфляція знаходиться в допустимих межах, а банки мають досить капіталу та ліквідності, щоб відновити кредитування економіки, що дасть змогу подолати сучасну кризу та відновити економічний розвитку України.

Дослідження сучасних монетарних інструментів дало змогу виявити, що засоби та методи грошово-кре-

\begin{tabular}{|c|c|c|c|c|c|c|c|}
\hline Рік & 2014 & 2015 & 2016 & 2017 & 2018 & 2019 & 2020 \\
\hline $\begin{array}{l}\text { Макроекономічні } \\
\text { умови }\end{array}$ & $\begin{array}{c}\text { Розпал } \\
\text { кризи }\end{array}$ & $\begin{array}{r}\text { Стабі } \\
\text { фіна } \\
\text { сис }\end{array}$ & $\begin{array}{l}\text { ізація } \\
\text { сової } \\
\text { еми }\end{array}$ & $\begin{array}{r}\text { Екон } \\
\text { зрос }\end{array}$ & $\begin{array}{l}\text { мічне } \\
\text { ання }\end{array}$ & $\begin{array}{c}\text { Економічне } \\
\text { зростання }\end{array}$ & \\
\hline $\begin{array}{l}\text { Монетарний } \\
\text { режим }\end{array}$ & $\begin{array}{c}\text { Еклектична } \\
\text { політика }\end{array}$ & $\begin{array}{r}\text { Моне } \\
\text { таргет } \\
\text { / Плав } \\
\text { валю } \\
\text { ку }\end{array}$ & $\begin{array}{l}\text { гарне } \\
\text { вання } \\
\text { ючий } \\
\text { гний } \\
\text { с }\end{array}$ & $\begin{array}{r}\text { Інфль } \\
\text { таргет } \\
\text { / Плав } \\
\text { валю } \\
\text { ку }\end{array}$ & $\begin{array}{l}\text { Lійне } \\
\text { вання } \\
\text { ючий } \\
\text { гний } \\
\text { с }\end{array}$ & $\begin{array}{r}\text { Інфляцій } \\
\text { таргетуван } \\
\text { Плаваюч } \\
\text { валютний }\end{array}$ & $\begin{array}{l}\text { не } \\
\text { ня / } \\
\text { ий } \\
\text { курс }\end{array}$ \\
\hline $\begin{array}{l}\text { Цілі монетарної } \\
\text { політики }\end{array}$ & $\begin{array}{l}\text { Стабалізація } \\
\text { фінансової } \\
\text { системи }\end{array}$ & $\begin{array}{l}\text { Дезінд } \\
\text { попоп } \\
\text { міжна } \\
\text { резерв } \\
\text { стабіл } \\
\text { валюті } \\
\text { ринку }\end{array}$ & $\begin{array}{l}\text { чяція, } \\
\text { нення } \\
\text { одних } \\
\text { з, } \\
\text { ація } \\
\text { ого }\end{array}$ & $\begin{array}{l}\text { Цінова } \\
\text { сабіль } \\
\text { попоп } \\
\text { міжна } \\
\text { резерв }\end{array}$ & $\begin{array}{l}\text { ість, } \\
\text { нення } \\
\text { одних } \\
\text {, }\end{array}$ & $\begin{array}{l}\text { Цінова } \\
\text { сабільність, } \\
\text { попопвнення }\end{array}$ & \\
\hline $\begin{array}{l}\text { Основні } \\
\text { монетарні } \\
\text { інструменти }\end{array}$ & $\begin{array}{l}\text { облікова став } \\
\text { доповнювала } \\
\text { постійно дію } \\
\text { кредитним та } \\
\text { депозитним } \\
\text { механізмами } \\
\text { овернайт }\end{array}$ & $\begin{array}{l}\text { ка, яка } \\
\text { ся } \\
\text { ними }\end{array}$ & & & & & \\
\hline
\end{tabular}

Рис. 1. Основні передумови та характеристики формування й реалізації монетарної політики в Україні у 2014-2019 рр.

Джерело: власна розробка автора 
дитної політики НБУ використовуються насамперед для контролю впливу монетарних чинників на стабільність грошової одиниці. Навіть якщо певні інструменти і впливають на функціонування кредитного ринку та вливання інвестицій, то все одно кінцевою метою їх застосування $є$ досягнення відповідних монетарних показників та фінансової стабільності у державі.

Якщо монетарна політика в Україні і надалі буде залишатися досить жорсткою, а НБУ не буде мати можливості використовувати емісійний ресурс для впливу на розвиток національної економіки та не буде впливати на збільшення обсягів внутрішнього кредитування через кредитний та фондовий канали, то очевидно, що розширення інвестицій в необхідних обсягах буде неможливим [10, с. 57].

Висновки. Можемо констатувати, що монетарна політика України $є$ важливим інструментом регулювання економіки. Підвищення іiі дієвості та ефективності позитивно впливає на соціально-економічне становище країни загалом та дасть змогу подолати сучасний кризовий стан фінансової системи, спричинений пандемією.

Основним інструментом в арсеналі НБУ є активне використання та коригування ключової процентної ставки. Саме iï зниження в квітні 2020 р. стане стимулом для активізації діяльності банків та позитивно вплине на економічний розвиток.

У контексті оптимізації розроблення та реалізації монетарної політики НБУ повинен і надалі підвищувати прозорість своєї діяльності шляхом розкриття повної, достовірної інформації щодо базових напрямів своєї діяльності. Такі дії сприятимуть підвищенню довіри до регулятора 3 боку громадськості та більш чіткому розумінню його дій монетарної політики.

Монетарна політика Національного банку і надалі повинна бути спрямована на підтримання режиму плаваючого обмінного курсу та нарощення рівня міжнародних резервів, а також здійснення контролю за зростанням грошових агрегатів, відповідно до програми співпраці з МВФ.

\section{Список літератури:}

1. Монетарна політика Національного банку України: сучасний стан та перспективи змін / Стельмах В.С. та ін.; ЦНД НБУ, УБС НБУ. Київ, 2009. 404 с.

2. Мишкін Ф.С. Економіка грошей, банківської справи і фінансових ринків. Київ: Основи, 1999. 963 с.

3. Дзюблюк О. Грошово-кредитна політика як фактор макроекономічної стабілізації і подолання наслідків кризових явищ. Світ фінансів. 2011. № 3. С. 7-19.

4. Коваленко В.В. Грошово-кредитна політика та ії вплив на подолання структурних дисбалансів економіки України. Вісник Миколаївського національного університету ім. В.О. Сухомлинського. 2016. № 12. С. 445-449.

5. Мищенко С.В. Проблемы устойчивости денежного обращения. М.: Новое знание, 2014. 399 с.

6. Про Державний бюджет України на 2018 рік. [Електронний ресурс]: Закон України № 2246-VIII від 07.12.2017 p. URL: https://zakon.rada.gov.ua/laws/show/2246-19. (дата звернення: 21.04.2020)

7. Основні засади грошово-кредитної політики на 2019 рік та середньострокову перспективу. НБУ Київ 2018.

8. Про Державний бюджет України на 2019 рік. Закон України // Відомості Верховної Ради (ВВР), 2018, № 50, ст. 400 URL: https://zakon.rada.gov.ua/laws/show/262919?find=1\&text=\%B3\%ED\%F4\%EB\%FF\%F6. (дата звернення: 21.04.2020)

9. Пропозиції стосовно розроблення Основних засад грошово-кредитної політики на 2016-2020 роки. URL: https://zakon.rada.gov.ua/laws/main/v0541500-15. (дата звернення: 22.04.2020)

10. Савлук М.І. Трансформація функціональних завдань НБУ в умовах системної розбалансованості економіки. Фінанси України. 2016, 57 с.

11. Підсумки дискусії членів Комітету з монетарної політики Національного банку України щодо рівня облікової ставки 22 квітня 2020 року. URL: https://bank.gov.ua/news/all/pidsumki-diskusiyi-chleniv-komitetu-z-monetarnoyi-politikinatsionalnogo-banku-ukrayini-schodo-rivnya-oblikovoyi-stavki-22-kvitnya-2020-roku. (дата звернення: 22.04.2020)

12. Дзюблюк О. Проблеми інфляційного таргетування в сучасній економіці. Світ фінансів. 2015. № 2. С. 7-18.

13. Сомик А.В. Еволюція основних засад грошово-кредитної політики в аспекті визначення монетарного та валютного режимів / А. В. Сомик // Вісник Української академії банківської справи. 2013. № 1 (34). С. 37-44.

14. Мищенко С.В. Современные проблемы теории денег и денежного обращения / ЦНИ НБУ, УБД НБУ. Киев, $2011,230 \mathrm{c}$

15. Основні засади грошово-кредитної політики на 2014 рік [Електронний ресурс] : рішення Ради Національного банку України. URL: http://bank.gov.ua/ doccatalog/document?id=7466694. (дата звернення: 22.04.2020)

16. Основні засади грошово-кредитної політики на 2015 рік. [Електроний ресурс] : Рішення Ради Національного банку України від 11 вересня 2014 р. № 28. URL: http://www.bank.gov.ua /doccatalog/document?id=10465306. (дата звернення: 23.04.2020)

\section{References:}

1. Stel 'max V.S. (2009) Monetarna polity 'ka Nacional’nogo banku Ukrayiny': suchasny`j stan ta perspekty 'vy`zmin, [Monetary policy of the National Bank of Ukraine: current state and prospects of changes]. CzND NBU, UBS NBU. Kyiv, 404 p. 
2. My’shkin F.C. (1999) Ekonomika groshej, bankivs'koyi spravy` i finansovy`x ry`nkiv [Economy of money, banking and financial markets]. Kyiv: Osnovy', 963 s.

3. Dzyublyuk O. (2011) Hroshovo-kredytna polityka yak faktor makroekonomichnoi stabilizatsii i podolannia naslidkiv kryzovykh yavyshch [Monetary policy as factor of macroeconomic stabilization and overcoming consequences of the crisis phenomena]. Svit finansiv, no. 3, pp. 7-19.

4. Kovalenko V.V. (2016) Hroshovo-kredytna polityka ta yii vplyv na podolannia strukturnykh dysbalansiv ekonomiky Ukrainy. [Monetary policy and its influence on overcoming structural imbalances of economy of Ukraine]. Visnyk Mykolaivskoho natsionalnoho universytetu im. V.O. Sukhomlynskoho, no. 12, pp. 445-449.

5. Myshchenko S.V (2014) Problemы ustoichyvosty denezhnoho obrashchenyia [Problems of cash circulation stability]. Moskva: Novoe znany`e, 399 s.

6. Pro Derzhavnyi biudzhet Ukrainy na 2018 rik. Zakon Ukrainy № 2246-VIII vid 07.12.2017 r [About the State Budget of Ukraine for 2018. Law of Ukraine № 2246-VIII of 07.12.2017]. Available at: https://zakon.rada.gov.ua/laws/show/2246-19. (accessed 21 April 2020)

7. Osnovni zasady hroshovo-kredytnoi polityky na 2019 rik ta serednostrokovu perspektyvu (2018) [The main bases of monetary policy for 2019 and the medium term] NBU Kiyv.

8. Pro Derzhavnyi biudzhet Ukrainy na 2019 rik. Zakon Ukrainy (2018) [The law of Ukraine on the State budget of Ukraine for 2019]. Vidomosti Verkhovnoi Rady (VVR), 2018, № 50, st. 400. Available at: https://zakon.rada.gov.ua/laws/sho w/262919? find $=1 \&$ text=\%B3\%ED\%F4\%EB\%FF\%F6. (accessed 21 April 2020)

9. Propozytsii stosovno rozroblennia Osnovnykh zasad hroshovo-kredytnoi polityky na 2016-2020 roky [Offers on development of the basic principles of monetary policy for 2016-2020]. Available at: https://zakon.rada.gov.ua/laws/main/ v0541500-15. (accessed 22 April 2020)

10. Savluk M.I. (2016) Transformatsiia funktsionalnykh zavdan NBU v umovakh systemnoi rozbalansovanosti ekonomiky [Transformation of functional tasks of the NBU in the conditions of system unbalance of economy]. Finansy Ukrainy, $57 \mathrm{~s}$.

11. Pidsumky dyskusii chleniv Komitetu z monetarnoi polityky Natsionalnoho banku Ukrainy shchodo rivnia oblikovoi stavky 22 kvitnia 2020 roku [Results of a discussion of members of the committee on the monetary policy of the National Bank of Ukraine concerning the level of discount rate on April 22, 2020]. Available at: https://bank.gov.ua/news/all/pidsumkidiskusiyi-chleniv-komitetu-z-monetarnoyi-politiki-natsionalnogo-banku-ukrayini-schodo-rivnya-oblikovoyi-stavki-22kvitnya-2020-roku. (accessed 22 April 2020)

12. Dzyublyuk O. (2015) Problemy infliatsiinoho tarhetuvannia v suchasnii ekonomits [Problems of inflation targeting in the modern economy]. Svit finansiv, no. 2, pp. 7-18.

13. Somy`k A.V. (2013) Evoliutsiia osnovnykh zasad hroshovo-kredytnoi polityky v aspekti vyznachennia monetarnoho ta valiutnoho rezhymiv [Evolution of the basic principles of monetary policy in terms of determining the monetary and exchange rate regimes]. Visnyk Ukrainskoi akademii bankivskoi spravy, no. 1 (34), pp. 37-44.

14. Myshchenko S.V. (2011) Sovremennue problemы teoryy deneh y denezhnoho obrashchenyia [Modern problems of the theory of money and money circulation]. CzNY` NBU, UBD NBU. Ky'ev, $230 \mathrm{~s}$.

15. Osnovni zasady hroshovo-kredytnoi polityky na 2014 rik: rishennia Rady Natsionalnoho banku Ukrainy [Basic principles of monetary policy for 2014: decision of the Council of the National Bank of Ukraine.]. Available at: http://bank.gov.ua/ doccatalog/document?id=7466694. (accessed 22 April 2020)

16. Osnovni zasady hroshovo-kredytnoi polityky na 2015 rik.: Rishennia Rady Natsionalnoho banku Ukrainy vid 11 veresnia 2014 r. № 28. [Basic principles of monetary policy for 2015: Decision of the Council of the National Bank of Ukraine of September 11, 2014 № 28]. Available at: http://www.bank.gov.ua /doccatalog/document?id=10465306. (accessed 23 April 2020)

\section{СОВРЕМЕННЫЕ ТЕНДЕНЦИИ И ИНСТРУМЕНТЫ МОНЕТАРНОЙ ПОЛИТИКИ В УКРАИНЕ}

В статье рассмотрена и проанализирована роль монетарного регулирования и функции Национального банка Украины в стимулировании экономического развития в условиях финансовой нестабильности. Автор исследовал основные приниипы монетарной политики НБУ в 2010-2020 г2., а также инструменты и монетарные индикаторы развития денежно-кредитной сферы. Особое внимание акцентировано на основных тенденщиях монетарной политики НБУ в течение 2014-2020 г2. На основе классификачии тендениий современной монетарной политики НБУ автор пришел к выводу, что большинство проблем, которые препятствовали реализации эффективной денежно-кредитной политики и развитию банковской системы, преодолены: инфлячия находится в допустимых пределах, банки имеют достаточно капитала и ликвидности, чтобы возобновить кредитование экономики, что позволит преодолеть современный кризис и восстановить экономическое развития Украины.

Ключевые слова: Наџиональный банк Украины, монетарная политика, глобальный финансовый кризис, девальвация и инфляция, монетарные инструменты, функиии центтрального банка. 


\section{CURRENT TRENDS AND MONETARY POLICY INSTRUMENTS IN UKRAINE}

In article it is considered and it is analysed a role of monetary regulation, value and function of the Central bank of Ukraine in stimulation of economic development in the conditions of financial instability. The basic principles of monetary policy of the National Bank of Ukraine during the period from 2009 to 2020 which the Central bank realized and intends to realize in the current year and in the medium term for achievement of goals and also concerning the used tools and monetary indicators of development of the monetary and credit sphere. Allocated top trends of monetary policy of the National Bank of Ukraine during 2014-2019. On the basis of classification of trends of modern monetary policy of National bank, the author drew conclusions that the majority of problems which interfered with realization of effective monetary policy and development of a banking system is overcome: Inflation is in allowable limits, and banks have enough capital and liquidities to resume crediting of economy that will become a reliable basis for ensuring sustainable economic development of Ukraine. A study of modern monetary instruments made it possible to discover that the means means and methods of monetary policy of the NBU are used first of all for control of influence of monetary factors on stability of monetary unit. Even if certain tools also influence functioning of the credit market and to injection of investments, then all the same ultimate goal of their application is achievement of the corresponding monetary indicators and financial stability in the state. Global financial crisis of 2008-2009 showed the inaccuracy understanding of function of the central bank as achievement of one purpose - ensuring low inflation. After 2008. The developed countries use a new paradigm of the central banking - multi targeting which expands the list of the purposes and diversifies the tools used for their achievement. The role of the central banks in a financial system of monetary regulation of economy considerably extended and became complicated. Their value in management of monetization and stimulation of economic growth grew. They are forced to combine performance of functions on implementation of economic policy, especially in the sphere of currency and crisis management, control of inflation and ensuring financial stability.

Key words: National Bank of Ukraine, monetary policy, global financial crisis, devaluation and inflation, monetary tools, functions of the central bank. 